\title{
EFFECT OF SODIUM NITROPRUSSIDE ON COMPLEMENT ACTIVATION INDUCED BY CARDIOPULMONARY BYPASS: A CLINICAL AND EXPERIMENTAL STUDY
}

Marie-Christine Seghaye, $\mathrm{MD}^{\mathrm{a}}$

Jean Duchateau, MD $^{\mathrm{b}}$

Ralph G. Grabitz, $\mathrm{MD}^{\mathrm{a}}$

Thibault Wolff

Christiane Marcus, MD

Wolfgang Engelhardt, $\mathrm{MD}^{\mathrm{a}}$

Helmut Hörnchen, $\mathrm{MD}^{\mathrm{d}}$

Bruno J. Messmer, MD

Goetz von Bernuth, MD
Complement activation and leukocyte stimulation were prospectively studied during and after cardiopulmonary bypass in 16 children receiving sodium nitroprusside - a nitrovasodilator releasing nitric oxide-for vasodilation during the cooling and rewarming periods of extracorporeal circulation. Results were compared with those in 29 patients who were not treated with sodium nitroprusside during the operation. Patients treated with sodium nitroprusside had significantly less C3 conversion during cardiopulmonary bypass as measured by the ratio $\mathrm{C} 3 \mathrm{~d} / \mathrm{C3}(p<0.05)$ and significantly less $\mathrm{C5a}$ liberation immediately after cardiopulmonary bypass $(p<0.005)$ than patients not treated with sodium nitroprusside. $\mathrm{C} 4$ was not overtly consumed in our series. Leukocyte count during the rewarming period of cardiopulmonary bypass, but not leukocyte elastase release during cardiopulmonary bypass, was significantly reduced in patients treated with sodium nitroprusside $(p<0.05)$. In vitro experiments were conducted to analyze the effect of sodium nitroprusside on complement hemolytic activity initiated by the classic and the alternate pathways and on zymosan-induced $\mathrm{C} 3$ conversion by the activation of the alternate pathway. The in vitro experiments clearly demonstrate inhibition of complement hemolytic activity by sodium nitroprusside in the sera tested. The $\mathbf{5 0 \%}$ inhibitory concentration of sodium nitroprusside on the available complement hemolytic activity was less through the alternate pathway than through the classic one $(4.2 \pm 0.8 \mathrm{mmol} / \mathrm{L}$ and $14.0 \pm 2.88 \mathrm{mmol} / \mathrm{L}$, respectively). The decrease of complement hemolytic activity measured was dose-dependent and was enhanced by the sodium nitroprusside preincubation of the sera tested. This effect was related to the duration of preincubation. Sodium nitroprusside photodegradation (enhancing nitric oxide release) increased the anticomplementary effect of the drug, reducing the $50 \%$ inhibitory concentration on complement hemolytic activity to 0.24 to $0.02 \mathrm{mmol} / \mathrm{L}$ for the alternate pathway and $2.74 \mathrm{o} 0.3 \mathrm{mmol} / \mathrm{L}$ for the classic pathway. The zymosan-induced $\mathrm{C} 3$ conversion was inhibited by sodium nitroprusside. Nitroglycerin and isosorbide dinitrate (other nitric oxide donors) had in vitro effects on complement hemolytic activity similar to those of nonphotodegraded sodium nitroprusside at similar concentrations $(1 \mathrm{mmol} / \mathrm{L})$. Our results suggest that sodium nitroprusside, both in vitro and in vivo, has an inhibiting effect on complement activation initiated by both classic and alternate pathways and that this effect is mediated by
From the Departments of Pediatric Cardiology, ${ }^{\text {a }}$ Anesthesiology, ${ }^{\mathrm{c}}$ Pediatric Intensive Care, ${ }^{\mathrm{d}}$ and Thoracic and Cardiovascular Surgery, ${ }^{\mathrm{e}}$ Rheinisch-Westfälische Technische Hochschule Aachen, Aachen, Germany, and the Department of

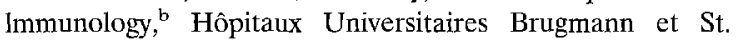
Pierre, Université Libre de Bruxelles, Brussels, Belgium.

This article is dedicated to the memory of Thibault Wolff.

Received for publication Nov. 21, 1994; accepted for publication June 14, 1995.
Address for reprints: Marie-Christine Seghaye, MD, Department of Pediatric Cardiology, RWTH Aachen, Pauwelsstrasse 30, D-52057, Aachen, Germany.

J ThoraC CARDIOvasC Surg 1996;111:882-92.

Copyright (C) 1996 by Mosby-Year Book, Inc.

$0022-5223 / 96 \$ 5.00+0 \quad 12 / 1 / 67038$ 


\begin{abstract}
nitric oxide release from sodium nitroprusside. This is the first report on the anticomplementary effect of sodium nitroprusside by nitric oxide release. (J Thorac Cardiovasc Surg 1996;111:882-92)
\end{abstract}

$T^{\mathrm{h}}$ he complex generalized inflammatory reaction resulting from cardiopulmonary bypass (CPB) involves the liberation of various humoral and intracellular mediators that could be related to the development of postoperative organ dysfunction, the pathophysiologic basis of which includes the loss of endothelial integrity. ${ }^{1,2}$ Complement activation, by contact between blood and foreign surfaces and by its interactions with other biologic cascades, ${ }^{3}$ is thought to play a central role in this inflammatory reaction. ${ }^{1,4,5}$ Complement anaphylatoxins $\mathrm{C} 3 \mathrm{a}$ and $\mathrm{C} 5 \mathrm{a}$ are potent leukocyte chemotactic factors, inducing leukocyte stimulation with proteolytic enzyme and oxygen-derived free radical release and cytokine production, ${ }^{5-12}$ which in turn may be involved in the development of postoperative organ injury. $5,9,13,14$ Several therapeutic interventions have been proposed to prevent or limit the magnitude of the inflammatory reaction occurring during $\mathrm{CPB}$. These include nonspecific treatment with conflicting clinical and experimental results such as, among others, the preoperative administration of corticosteroids, ${ }^{15-17}$ of the protease inhibitor aprotinin, ${ }^{18-20}$ or of methylxanthine pentoxifylline, which inhibits the inflammatory action of interleukin- 1 and tumor necrosis factor- $\alpha .^{21,22} \mathrm{~A}$ more specific approach, the administration of human recombinant soluble complement receptor 1 , which inhibits classic, alternate, and terminal pathway activation of the complement cascade, was recently investigated in an animal model. ${ }^{23}$ Because complement activation may play a central role in the $\mathrm{CPB}$-induced inflammatory reaction, the attenuation of complement activation makes this therapeutic approach rational.

We here report the effect of sodium nitroprusside (SNP), a long known vasodilator ${ }^{24}$ and nitric oxide donor, ${ }^{25}$ on complement activation and leukocyte mobilization occurring during CPB. Inasmuch as our clinical observations suggested an in vivo inhibitory effect of SNP on complement activation induced by $\mathrm{CPB}$, we verified this hypothesis by in vitro experiments. We document for the first time the influence of this drug on both the alternate and the classic pathways of complement activation and discuss its mechanism of action.

\section{Patients and methods}

Clinical. Sixteen infants and children aged 6 months to 7 years (mean age 29 months) undergoing cardiac operations for congenital cardiac defects were included in this prospective study. Diagnoses and types of surgical procedures are shown in Table I. These 16 patients were operated on at the same time as a group of 29 patients aged 3 months to 17 years (mean age 40 months) studied in the same way and reported on previously. ${ }^{13}$ The CPB protocol in both patient groups was identical with one exception: for vasodilation during the cooling and the rewarming periods of extracorporeal circulation, the 16 patients studied here received SNP systematically instead of phentolamine or they received no vasodilator at all.

Anesthesia and antibiotic regimen. Conventional general anesthesia was performed in all patients. Cefotiam hydrochloride $(25 \mathrm{mg} / \mathrm{kg})$ and dexamethasone $\left(3 \mathrm{mg} / \mathrm{m}^{2}\right)$ given for prophylaxis of cerebral edema were administered before sternotomy.

$C P B$. The CPB protocol was identical for the 16 children examined. A roller pump, a disposable membrane oxygenator, and an arterial filter were used. Cooling and rewarming were done with a heat exchanger. The priming solution consisted of a crystalloid solution, mannitol $(3 \mathrm{ml} / \mathrm{kg}$ ), and fresh whole blood. The hematocrit value of the circulating volume averaged $25 \%$. CPB was instituted after right atrial or bicaval and aortic cannulation with a perfusion index of $2.7 \mathrm{~L} / \mathrm{m}^{2}$. Heparinization was achieved with heparin sulfate (3 $\mathrm{mg} / \mathrm{kg}$ ). For vasodilation in the cooling period, all 16 children received a continuous infusion of SNP ( 0.6 to 2.9 $\mu \mathrm{g} / \mathrm{kg}$ per minute, average $1.7 \mu \mathrm{g} / \mathrm{kg}$ per minute). Aortic crossclamping was done and cardioplegia was induced by a single intraaortic injection of cold $\left(4^{\circ} \mathrm{C}\right)$ Bretschneider solution $(30 \mathrm{ml} / \mathrm{kg})$. In 12 children, the operation was performed under deep hypothermia (nasopharyngeal temperature averaging $16^{\circ} \mathrm{C}$ ) and circulatory arrest. Low-flow CPB was conducted (perfusion index averaging $25 \%$ of the initial one) when circulatory arrest reached 60 minutes. The other four children were operated on with low-flow CPB (nasopharyngeal temperature averaging $26^{\circ} \mathrm{C}$ ). In all children the lungs were reventilated when core temperature reached $30^{\circ}$ $\mathrm{C}$ and a continuous infusion of SNP was reinstituted at the beginning of rewarming ( 0.6 to $2.9 \mu \mathrm{g} / \mathrm{kg}$ per minute, average $1.6 \mu \mathrm{g} / \mathrm{kg}$ per minute). Anticoagulation during CPB was monitored by determination of activated clotting time. Heparin was neutralized with protamine sulfate $(6 \mathrm{mg} / \mathrm{kg})$ injected into the aorta. Catecholamines were administered if necessary for weaning the patients from CPB.

Postoperative care. In the intensive care unit, sedation and analgesia were maintained with diazepam and morphine sulfate. The catecholamine and vasodilatory regimen was adapted to the particular hemodynamic situation.

Beyond standard determinations of blood gas and serum electrolyte values, laboratory tests including liver 
Table I. Patient data

\begin{tabular}{|c|c|c|c|c|c|}
\hline $\begin{array}{l}\text { Patient } \\
\text { no. }\end{array}$ & $\begin{array}{l}\text { Age } \\
\text { (mo) }\end{array}$ & Diagnosis & $\begin{array}{l}\text { Surgical } \\
\text { procedure }\end{array}$ & Complications & Outcome \\
\hline 1 & 6 & Abnormal origin of LCA & LCA reimplantation & None & Discharged \\
\hline 2 & 12 & VSDs, ASD & VSD + ASD closure & None & Discharged \\
\hline 3 & 2 & LV tumor & Tumor extirpation & None & Discharged \\
\hline 4 & 12 & Down, AVSD & Repair & None & Discharged \\
\hline 5 & 39 & $\mathrm{AOS}, \mathrm{ASD}$ & Repair & None & Discharged \\
\hline 6 & 54 & TOF, ASD & Repair & None & Discharged \\
\hline 7 & 34 & Down, VSD & VSD closure & PPS & Discharged \\
\hline 8 & 7 & AVSD, MI & Repair & None & Discharged \\
\hline 9 & 11 & Down, AVSD & Repair & None & Discharged \\
\hline 10 & 10 & Down, AVSD & Repair & None & Discharged \\
\hline 11 & 16 & D-TGA, ASD & Senning & None & Discharged \\
\hline 12 & 51 & $\begin{array}{l}\text { TOF, RVOT enlargement } \\
\text { RV failure }\end{array}$ & Repair attempt & & $\begin{array}{l}\text { Died on operating } \\
\text { table }\end{array}$ \\
\hline 13 & 11 & TOF & Repair & None & Discharged \\
\hline 14 & 47 & $\begin{array}{l}\text { Single ventricle, TGA, CoA } \\
\text { CoA repair }+ \text { PAB }\end{array}$ & Fontan modified & MSOF & Died \\
\hline 15 & 66 & $\begin{array}{l}\text { DORV, L-TGA, hypoplastic } \\
\text { LV, sub-PS }\end{array}$ & Fontan modified & MSOF & Died \\
\hline 16 & 83 & $\begin{array}{l}\text { TGA, VSD; Senning, VSD } \\
\text { closure; sub-PS, VSD }\end{array}$ & $\begin{array}{l}\text { VSD closure } \\
\text { LVOT enlargement }\end{array}$ & $\begin{array}{l}\text { AVB III } \\
\text { PM }\end{array}$ & Discharged \\
\hline
\end{tabular}

LCA, Left coronary artery; VSD, ventricular septal defect; $\overline{A S D}$, atrial septal defect; $D o w n$, Down syndrome; $A V S D$, atrioventricular septal defect; $A O S$, aortic stenosis; $T O F$, tetralogy of Fallot; $M I$, mitral insufficiency; $T G A$, transposition of the great arteries; $R V O T$, right ventricular outflow tract; $R V$, right ventricular; $C O A$, coarctation of the aorta; $P A B$, pulmonary artery banding; $P S$, pulmonary stenosis; $P P S$, postpericardiotomy syndrome; $M S O F$, multiple organ system failure; $A V B$, atrioventricular block; $P M$, pacemaker implantation.

Table II. Sample time schedule

\begin{aligned} & \hline 1 Preoperative \\ & 2 After heparin administration \\ & 3 Ten minutes after onset of CPB \\ & 4 Lungs reventilated \\ & 5 Core temperature $>30^{\circ} \mathrm{C} \\ & 6$ After protamine administration \\ & 7 First postoperative day $(9: 00 \mathrm{AM}) \\ & 8$ Second postoperative day $(9: 00 \mathrm{AM}) \\ & 9$ Third postoperative day $(9: 00 \mathrm{AM}) \\ & 10$ Fifth postoperative day $(9: 00 \mathrm{AM}) \\ & 11$ Seventh postoperative day $(9: 00 \mathrm{AM}) \\ &$\hline\end{aligned}

enzyme and serum creatinine concentrations and coagulation times were routinely performed at least twice a day. Thiocyanate levels were monitored if indicated. Multiple system organ failure was diagnosed on the basis of our previous definition. ${ }^{13}$

Collection of samples. Venous blood was collected before and after the operation. During CPB blood was withdrawn from the arterial line of the circuit. For each sample time, $2 \mathrm{ml}$ of blood taken in tubes containing ethylenediaminetetraacetic acid was necessary for analyzing complement factors and $0.3 \mathrm{ml}$ for leukocyte count and differentiation. The sample time schedule is shown in Table II.

Determination of complement factors. The samples for complement analysis were immediately centrifuged for 3 minutes $(3000 \mathrm{rpm})$ and the plasma was stored at $-70^{\circ} \mathrm{C}$ until analysis.

C3 and C4 were determined by standard methods of turbidimetry $^{26}$ with the use of the immunoglobulin $G$ faction of a rabbit antihuman $\mathrm{C} 3$ or $\mathrm{C} 4$ antiserum with an automated procedure on an RA 1000 turbidimeter (Technicon, Brussels, Belgium).

For $\mathrm{C} 3 \mathrm{~d}$ determination, the sample was incubated (volume/volume) with borate buffer containing $22 \%$ polyethylene glycol for 1 night at $4^{\circ} \mathrm{C}$. After centrifugation to discard the $\mathrm{C} 3$ molecules, the supernatant was analyzed by turbidimetry as described for $\mathrm{C} 3$ and $\mathrm{C} 4$ with the following modifications: the sample diluent was supplemented with $20 \%$ distilled water to allow a reduction of polyethylene glycol to a maximum of $3.5 \%$ in the reaction mixture during immunoprecipitation.

C5a was determined by enzyme immunoassay (Enzygnost C5a, Behring, Hoechst, Brussels, Belgium). Normal range for healthy adults is 0.15 to $0.45 \mu \mathrm{g} / \mathrm{L}$.

Elastase was measured with immunoactivation enzyme immunoassay (Merck, Darmstadt, Germany). Normal values for healthy adults are $22 \pm 10 \mu \mathrm{g} / \mathrm{L}$.

Leukocyte count and differentiation were determined by a Coulter counter (Coulter Electronics, Inc., Hialeah, Fla.). Inasmuch as several individual factors such as postoperative catecholamine administration possibly influence leukocyte count, circulating leukocytes were determined before $C P B$, during $C P B$, and after protamine administration, but not later. Leukocyte count was corrected for hemodilution according to the following formula: $\mathrm{L}_{\mathrm{c}}=\mathrm{L}_{\mathrm{s}} \times\left(\mathrm{Ht}_{\mathrm{c}} / \mathrm{Ht}_{\mathrm{s}}\right)$, where $\mathrm{L}_{\mathrm{c}}=$ corrected leukocytes, $\mathrm{L}_{\mathrm{s}}=$ sample leukocytes, $\mathrm{Ht}_{\mathrm{c}}=$ control hematocrit, and $\mathrm{Ht}_{\mathrm{s}}=$ sample hematocrit.

The other values determined during CPB were not corrected for hemodilution, because we considered the measured concentrations to be biologically relevant.

\section{In vitro experimentation}

Experimental schedule. Sera taken from healthy blood donors from the "Centre Albert Hustin," Brussels, were 
analyzed for complement hemolytic activity $\left(\mathrm{CH}_{50}\right)$ in the presence of increasing SNP concentrations (1 to 16 mmol/L; molecular weight of SNP $=298) . \mathrm{CH}_{50}$ also was measured after various periods of preliminary incubation $(15,30,60$, and 120 minutes) with a minimal active concentration of SNP $(0.6 \mathrm{mmol} / \mathrm{L})$. This was repeated after light degradation of SNP by ultraviolet exposure of the SNP solution for 20 minutes. The effect of SNP on zymosan-induced C3d generation and, finally, the effect of nitroglycerin and isosorbide dinitrate on $\mathrm{CH}_{50}$ were also studied.

$\mathrm{CH}_{50}$. The alternate pathway was evaluated with a quantitative microassay, with rabbit erythrocytes used as target cells in the presence of ethyleneglycoltetraacetic acid- $\mathrm{Mg}^{++}$-veronal gelatin dextrose buffer, in microtiter plates after six serial dilutions of serum samples. Hemolysis was measured with an MR 5000 microplate reader (Dynatech; van der Heyden, Brussels, Belgium) at 630 $\mathrm{nm}$, according to our previously described methods. ${ }^{27}$

The classic pathway was determined in the same manner as the alternate pathway with sheep erythrocytes sensitized with rabbit hemolysin in $\mathrm{Ca}^{++}-\mathrm{Mg}^{++}$-veronal gelatin dextrose buffer.

Chemicals. SNP (Nipride, Roche), nitroglycerin (Nysconitrine, Bio-Therabel), and isosorbide dinitrate (Cédocard, Céocard, Byk Belga) solutions used were provided from the hospital pharmacy. Control solutions were prepared with ferrocyanide and potassium cyanide obtained from the laboratory (Merck, Belgolabo, Belgium) and the hospital pharmacy, respectively.

Statistical analysis. Results are expressed in the text and in the tables by the mean value \pm standard deviation (SD) and in the figures by the mean \pm standard error of the mean (SEM). For analysis of time-dependent variations of parameters within the same group, one-way analysis of variance for multiple comparisons with Scheffe's correction procedure was used. Comparisons of values between two groups in the clinical and experimental studies were done with the nonparametric Mann-Whitney $\mathrm{U}$ test or the paired Wilcoxon test. The paired $t$ test was used for analysis of in vitro experiments on small series $(n=5) \cdot \chi^{2}$ Analysis was performed with Yates' correction for occasional low cell values. The data were computerized and analyzed with the SPSS software (SPSS Inc., Chicago, Ill.). All $\mathrm{p}$ values lower than 0.05 were considered significant.

\section{Results}

Clinical results. Clinical data of the 16 patients are shown in Table I. The results of the present study are described and briefly compared with the results of our previous work, ${ }^{13}$ which are presented as our own reference values.

Durations of CPB, aortic crossclamping, and circulatory arrest averaged 82 minutes (range 35 to 273 minutes), 63 minutes (range 29 to 124 minutes), and 48 minutes (range 6 to 59 minutes), respectively, and were identical to those of the previous group.

One child (patient 12) could not be weaned from extracorporeal circulation and died on the operating table because of severe right ventricular failure.
Multiple organ system failure developed in two children (patients 14 and 15) after modified Fontan procedures, and they died on the fifth and tenth postoperative days, respectively. Multiple organ system failure was less prevalent in the present study $(2 / 16)$ than in the previous group (8/29), but this difference reached a significance level of only 0.1 $\left(1-2 \alpha ; \chi^{2}\right.$ with Yates' correction). Postpericardiotomy syndrome developed on the sixth postoperative day in one child. The other patients had no postoperative complications.

Hematocrit values. Hematocrit values fell from a preoperative value of $42 \% \pm 11 \%$ (mean $\pm \mathrm{SD}$ ) to $28 \% \pm 5 \% 10$ minutes after induction of CPB. The hematocrit values remained stable during CPB and reached normal preoperative values from the immediate postoperative period on according to our previous observations.

Complement factors. All children had normal C3 values before the operation $(\mathrm{C} 3=121 \pm 25.5$ $\mathrm{mg} / \mathrm{dl}$ ) (mean $\pm \mathrm{SD}$ ). C3 concentrations fell to $56 \pm$ $12.5 \mathrm{mg} / \mathrm{dl}$ after induction of $\mathrm{CPB}$ and remained stable up to the end of CPB, after protamine administration $(\mathrm{C} 3=67.8 \pm 12.7 \mathrm{mg} / \mathrm{dl})$. $\mathrm{C} 3$ values rose slowly from the first postoperative day on and reached normal values on the fifth postoperative day, in accordance with our previous results.

$\mathrm{C} 3 \mathrm{~d} / \mathrm{C} 3$ was in the normal range before the operation in all children $(\mathrm{C} 3 \mathrm{~d} / \mathrm{C} 3=0.75 \pm 0.36)$ (mean $\pm \mathrm{SD}$ ). C3d/C3 rose from a value of $0.61 \pm$ 0.3410 minutes after institution of CPB (sample time 3) to $1.10 \pm 0.45$ after protamine administration (sample time 6). $\mathrm{C} 3$ conversion during $\mathrm{CPB}$ was significant $(p<0.001)$. C3d/C3 reached normal values from the first postoperative day on (sample time 7) $(\mathrm{C} 3 \mathrm{~d} / \mathrm{C} 3=0.80 \pm 0.45)$ and remained within the normal range during the first postoperative week. C3 conversion after protamine administration was significantly lower in the current patient group than in the previous one $(p=0.02)$. This was also true of the difference between $\mathrm{C} 3 \mathrm{~d} / \mathrm{C} 3$ measured after protamine administration (sample time 6) and initiation of CPB (sample time 3$)(p=0.02)$. Fig. 1 compares the course of $\mathrm{C} 3 \mathrm{~d} / \mathrm{C} 3$ in the current patient group with that in the previous one.

$\mathrm{C} 4$ was in the normal range before $\mathrm{CPB}$ in all children $(\mathrm{C} 4=19.8 \pm 8.35 \mathrm{mg} / \mathrm{dl})($ mean $\pm \mathrm{SD})$. After institution of CPB (sample time 3), the C4 value fell to $9.53 \pm 3.29 \mathrm{mg} / \mathrm{dl}$. C4 remained stable during CPB up to the end of CPB, after protamine administration (sample time 6$)(\mathrm{C} 4=11.4 \pm 3.5$ $\mathrm{mg} / \mathrm{dl}$ ). $\mathrm{C} 4$ reached preoperative values on the third postoperative day and remained in this range (sam- 


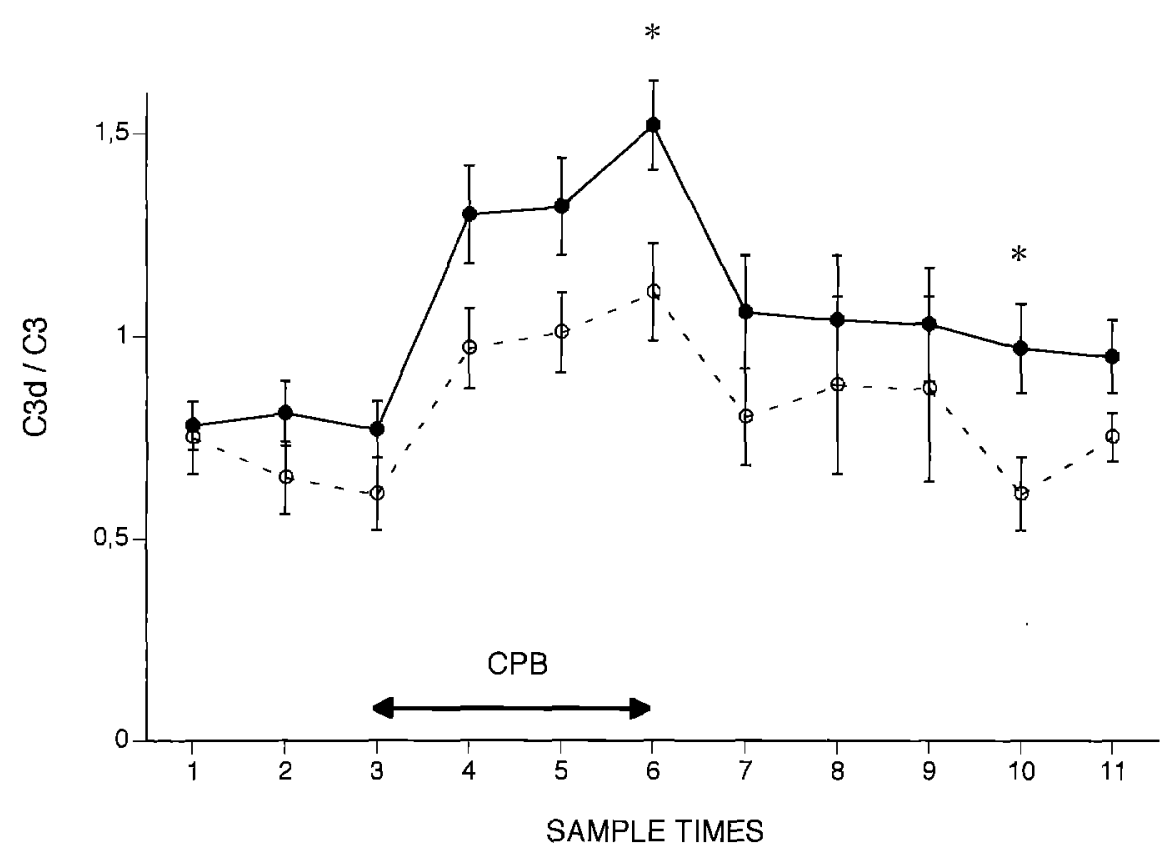

Fig. 1. Course of $\mathrm{C} 3 \mathrm{~d} / \mathrm{C} 3$ before, during, and after $\mathrm{CPB}$ in patients treated with SNP (intemupted line) ( $n=16$ until sample time $5, n=15$ until sample time 10 , and $n=13$ at sample time 11 ), and in patients not treated with SNP (solid line) ( $n=29$ until sample time $7, n=27$ at sample time $8, n=26$ until sample time 10 , and $n=22$ at sample time 11). Results are expressed by the mean \pm SEM. For sample time specification, see Table II. Asterisk indicates significant differences $(p<0.05)$ between the two groups (Mann-Whitney U test).

ple time 9) $(\mathrm{C} 4=15.1 \pm 7.3 \mathrm{mg} / \mathrm{dl})$. These results were identical to our previous results.

Compared with normal values in healthy adults (C5a $=0.15$ to $0.45 \mu \mathrm{g} / \mathrm{L}$ ), C5a values were elevated in all children after protamine administration (sample time 6$)(\mathrm{C} 5 \mathrm{a}=8.64 \pm 4.41 \mu \mathrm{g} / \mathrm{L})($ mean $\pm \mathrm{SD})$. They were significantly lower, however, than values reported in our reference group ( $\mathrm{C} 5 \mathrm{a}=18 \pm 11.8$ $\mu \mathrm{g} / \mathrm{L})(p<0.005)$.

Leukocytes and neutrophils. Leukocyte count fell from a preoperative value of $6.83 \pm 2.26 \times 10^{9} / \mathrm{L}$ (mean $\pm \mathrm{SD}$ ) to a value of $3.3 \pm 0.9 \times 10^{9} / \mathrm{L} 10$ minutes after induction of CPB (sample time 3) $(p<0.0001)$. Leukocyte counts remained stable during CPB but increased at the end of the rewarming period (sample time 5) (leukocyte count $=3.7 \pm$ $\left.3.3 \times 10^{9} / \mathrm{L}\right)(p<0.05)$, increasing significantly after protamine administration (sample time 6) (leukocyte count $\left.=11.3 \pm 5.9 \times 10^{9} / \mathrm{L}\right)(p<0.0001)$. Leukocyte count after lung reventilation (sample time 4) and at the end of the rewarming period (sample time 5) was significantly lower than our reference values $(p<0.02$ and $p<0.05$, respectively).

Neutrophil counts fell from a preoperative value of $3.3 \pm 2.3 \times 10^{9} / \mathrm{L}$ to $1.3 \pm 0.6 \times 10^{9} / \mathrm{L}$ at sample time $3(p<0.0001)$. Neutrophil counts remained stable during CPB but increased at the end of the rewarming period (sample time 5) (neutrophil count $\left.=1.8 \pm 2.6 \times 10^{9} / \mathrm{L}\right)(p<0.05)$, increasing significantly after protamine administration (sample time 6) (neutrophil count $\left.=7.8 \pm 4.4 \times 10^{9} / \mathrm{L}\right)(p<$ $0.0001)$. Neutrophil count after lung reventilation (sample time 4) was significantly lower than our reference values $(p<0.05)$.

Leukocyte elastase. Leukocyte elastase rose in all children from $106 \pm 59 \mu \mathrm{g} / \mathrm{L}$ (mean $\pm \mathrm{SD}$ ) 10 minutes after institution of CPB (sample time 3 ) to $418 \pm 244 \mu \mathrm{g} / \mathrm{L}$ after protamine administration (sample time 6). These values were identical to our reference values.

The data of the current patient group are compared with our reference data in Table III.

\section{In vitro experiments}

Effect of SNP on $\mathrm{CH}_{50}$ (classic and alternate pathways) measured in the serum of seven healthy subjects(Fig. 2). In the presence of SNP, we observed in all sera a dose-dependent reduction of the complement hemolytic activity as measured by $\mathrm{CH}_{50}$. The inhibitory effect of SNP on the alternate pathway occurred at a concentration that was three times less than the inhib- 
itory concentration on the classic pathway (50\% inhibitory concentration of SNP on $\mathrm{CH}_{50}, 4.2 \pm 0.8 \mathrm{mmol} / \mathrm{L}$ (mean $\pm \mathrm{SD}$ ) and $14.0 \pm 2.88 \mathrm{mmol} / \mathrm{L}$ for the alternate pathway and classic pathway, respectively).

Effect of photodegraded SNP on $\mathrm{CH}_{50}$ measured in the same sera. In comparison with the data shown before, the $50 \%$ inhibitory concentration of SNP on the available $\mathrm{CH}_{50}$ decreased to $0.2 \pm 0.02 \mathrm{mmol} / \mathrm{L}$ (mean \pm SD) for the alternate pathway $(p<0.001)$ and to $2.7 \pm 0.3 \mathrm{mmol} / \mathrm{L}$ for the classic pathway $(p<$ 0.001 ). Table IV summarizes the influence of nondegraded and photodegraded SNP on $\mathrm{CH}_{50}$.

Effect of the preincubation time with photodegraded SNP $(0.6 \mathrm{mmol} / \mathrm{L})$ on $\mathrm{CH}_{50}$ (classic pathway) measured in the serum of six healthy subjects (Fig. 3). We observed in all sera a time-related decrease in $\mathrm{CH}_{50}$ according to the period of preincubation with a suboptimal concentration of SNP of $0.6 \mathrm{mmol} / \mathrm{L}$.

Effect of SNP on zymosan-induced C3-conversion measured in the serum of five healthy subjects (Fig. 4). C3d averaged $4.3 \pm 0.8 \mu \mathrm{g} / \mathrm{ml}$ (mean $\pm \mathrm{SD}$ ) in the sera in which complement activation was blocked with ethylenediaminetetraacetic acid $(10 \mathrm{mmol} / \mathrm{L})$. In contrast, C3d increased to $22.8 \pm 5.1 \mu \mathrm{g} / \mathrm{ml}(p<$ $0.001)$ in control tubes in which sera were supplemented with magnesium-containing alternate pathway buffer, displaying an alternate pathway-induced C3 conversion caused by contact between serum and plastic surfaces. Addition of zymosan further increased C3d levels to $29.7 \pm 5.0 \mu \mathrm{g} / \mathrm{ml}(p<0.001)$. The presence of SNP $(8 \mathrm{mmol} / \mathrm{L})$ for 1 hour at $37^{\circ} \mathrm{C}$ in sera incubated in plastic tubes significantly reduced C3d levels after zymosan addition, to a value of $17.0 \pm 4.0 \mu \mathrm{g} / \mathrm{ml}(p<0.0001)$. This value also was significantly lower than the $\mathrm{C} 3 \mathrm{~d}$ value of the control sera $(p<0.001)$.

Effect of potassium ferrocyanide $(2 \mathrm{mmol} / \mathrm{L})$ and potassium cyanide $(2 \mathrm{mmol} / \mathrm{L})$ on $\mathrm{CH}_{50}$ measured in the serum of six healthy subjects. The SNP metabolites ferrocyanide and cyanide were not able to produce any inhibitory effect of SNP on $\mathrm{CH}_{50}$ (data not shown).

Comparative effect of nonphotodegraded SNP (1 mmol/L), nitroglycerin $(1 \mathrm{mmol} / \mathrm{L})$, and isosorbide dinitrate $(1 \mathrm{mmol} / \mathrm{L})$ on $\mathrm{CH}_{50}$ (alternate pathway) measured in the serum of six healthy subjects (Fig. 5). $\mathrm{CH}_{50}$ of the control sera was $74 \pm 10 \mathrm{U} / \mathrm{L}$ (mean \pm $\mathrm{SD}$ ). In comparison, $\mathrm{CH}_{50}$ of the sera treated with different vasodilators was in all cases reduced and reached $50 \pm 10 \mathrm{U} / \mathrm{L}$ for SNP $(p<0.05), 55 \pm 11$ $\mathrm{U} / \mathrm{L}$ for nitroglycerin $(p<0.05)$, and $54 \pm 11 \mathrm{U} / \mathrm{L}$ for isosorbide dinitrate $(p<0.05)$.
Table III. Comparative data analysis between patients treated with SNP and patients not treated with SNP

\begin{tabular}{|c|c|c|c|}
\hline Variables & $\begin{array}{c}\text { With SNP } \\
(n=16)\end{array}$ & $\begin{array}{c}\text { Without SNP } \\
\quad(n=29)\end{array}$ & p Value \\
\hline $\begin{array}{l}\text { Age (mo) } \\
\quad \text { (range, mean) }\end{array}$ & $6-84,29$ & $3-213,40$ & NS \\
\hline $\begin{array}{l}\mathrm{CPB}(\min ) \\
\quad(\text { range, mean })\end{array}$ & $35-273,82$ & $31-152,72$ & NS \\
\hline $\begin{array}{l}\mathrm{ACC}(\min ) \\
\quad \text { (range, mean) }\end{array}$ & $29-124,63$ & $7-105,56$ & NS \\
\hline $\begin{array}{l}\mathrm{CCA}(\mathrm{min}) \\
\quad \text { (range, mean) }\end{array}$ & $\begin{array}{l}6-59,46 \\
(n=12)\end{array}$ & $\begin{array}{c}6-60,44 \\
(n=18)\end{array}$ & NS \\
\hline $\operatorname{MSOF}(n)$ & 2 & 8 & $0.1 \dagger$ \\
\hline Deaths $(n)$ & 3 & 4 & NS \\
\hline \multicolumn{4}{|l|}{$\mathrm{C} 4(\mathrm{mg} / \mathrm{dL})$} \\
\hline $\mathrm{T}_{1}$ & $19.8 \pm 8.3$ & $21.6 \pm 8.0$ & NS \\
\hline $\mathrm{T}_{2}$ & $16.2 \pm 6.8$ & $18.2 \pm 6.0$ & NS \\
\hline $\mathrm{T}_{3}$ & $9.9 \pm 3.3$ & $9.5 \pm 3.3$ & NS \\
\hline $\mathrm{T}_{6}$ & $11.8 \pm 4.3^{*}$ & $11.4 \pm 3.5$ & NS \\
\hline \multicolumn{4}{|l|}{$\mathrm{C} 3 \mathrm{~d} / \mathrm{C} 3$} \\
\hline $\mathrm{T}_{1}$ & $0.75 \pm 0.36$ & $0.78 \pm 0.33$ & NS \\
\hline $\mathrm{T}_{2}$ & $0.65 \pm 0.34$ & $0.81 \pm 0.46$ & NS \\
\hline $\mathrm{T}_{3}$ & $0.61 \pm 0.34$ & $0.77 \pm 0.37$ & NS \\
\hline $\mathrm{T}_{6}$ & $1.11 \pm 0.45^{*}$ & $1.52 \pm 0.59$ & $<0.05 \ddagger$ \\
\hline \multicolumn{4}{|l|}{ C5a $(\mu \mathrm{g} / \mathrm{L})$} \\
\hline $\mathrm{T}_{6}$ & $8.6 \pm 4.4^{*}$ & $18.0 \pm 11.8$ & $<0.005 \ddagger$ \\
\hline \multicolumn{4}{|l|}{ WBC $\left(\times 10^{9} / \mathrm{L}\right)$} \\
\hline $\mathrm{T}_{1}$ & $6.8 \pm 2.2$ & $7.7 \pm 2.5$ & NS \\
\hline $\mathrm{T}_{2}$ & $7.2 \pm 2.1$ & $8.3 \pm 2.1$ & NS \\
\hline $\mathrm{T}_{3}$ & $3.3 \pm 2.3$ & $4.3 \pm 5.7$ & NS \\
\hline $\mathrm{T}_{4}$ & $2.8 \pm 1.5$ & $4.6 \pm 2.3$ & $<0.02 \ddagger$ \\
\hline $\mathrm{T}_{5}$ & $3.7 \pm 3.3$ & $7.1 \pm 6.1$ & $<0.05 \ddagger$ \\
\hline $\mathrm{T}_{6}$ & $11.3 \pm 5.9^{*}$ & $14.5 \pm 8.1$ & NS \\
\hline \multicolumn{4}{|l|}{$\mathrm{PN}\left(\times 10^{9} / \mathrm{L}\right)$} \\
\hline $\mathrm{T}_{1}$ & $3.3 \pm 2.2$ & $3.7 \pm 1.5$ & NS \\
\hline $\mathrm{T}_{2}$ & $3.4 \pm 1.7$ & $4.3 \pm 0.67$ & NS \\
\hline $\mathrm{T}_{3}$ & $1.3 \pm 0.6$ & $1.7 \pm 0.9$ & NS \\
\hline $\mathrm{T}_{4}$ & $1.0 \pm 0.9$ & $2.2 \pm 1.5$ & $<0.05$ \\
\hline $\mathrm{T}_{5}$ & $1.8 \pm 2.6$ & $2.7 \pm 1.8$ & NS \\
\hline $\mathrm{T}_{6}$ & $7.8 \pm 4.4^{*}$ & $8.7 \pm 3.0$ & NS \\
\hline \multicolumn{4}{|l|}{ Elastase $(\mu \mathrm{g} / \mathrm{L})$} \\
\hline $\mathrm{T}_{3}$ & $106 \pm 59$ & $79 \pm 37$ & NS \\
\hline $\mathrm{T}_{6}$ & $418 \pm 244^{*}$ & $355 \pm 245$ & NS \\
\hline
\end{tabular}

$S N P$, sodium nitroprusside; $C P B$, duration of cardiopulmonary bypass; $A C C$, duration of aortic crossclamping; $C C A$, duration of cardiocirculatory arrest; $M S O F$, multiple system organ failure; $W B C$, white blood cells; $P N$, peripheral neutrophils; $N S$, not significant. For sample times $1,2,3,4,5$, and 6, see Table II. Biologic results are expressed by the mean \pm SD.

${ }^{*} n=15$.

$\dagger \chi^{2}$ analysis with Yates' correction.

†̣ Mann-Whitney U test.

\section{Discussion}

The clinical observations of this study suggest that SNP influences CPB-induced complement activation. These patients treated with SNP had significantly lower C3-conversion and C5a liberation than did patients belonging to our previous group, who were not treated with SNP. ${ }^{13}$ In the current study, as 


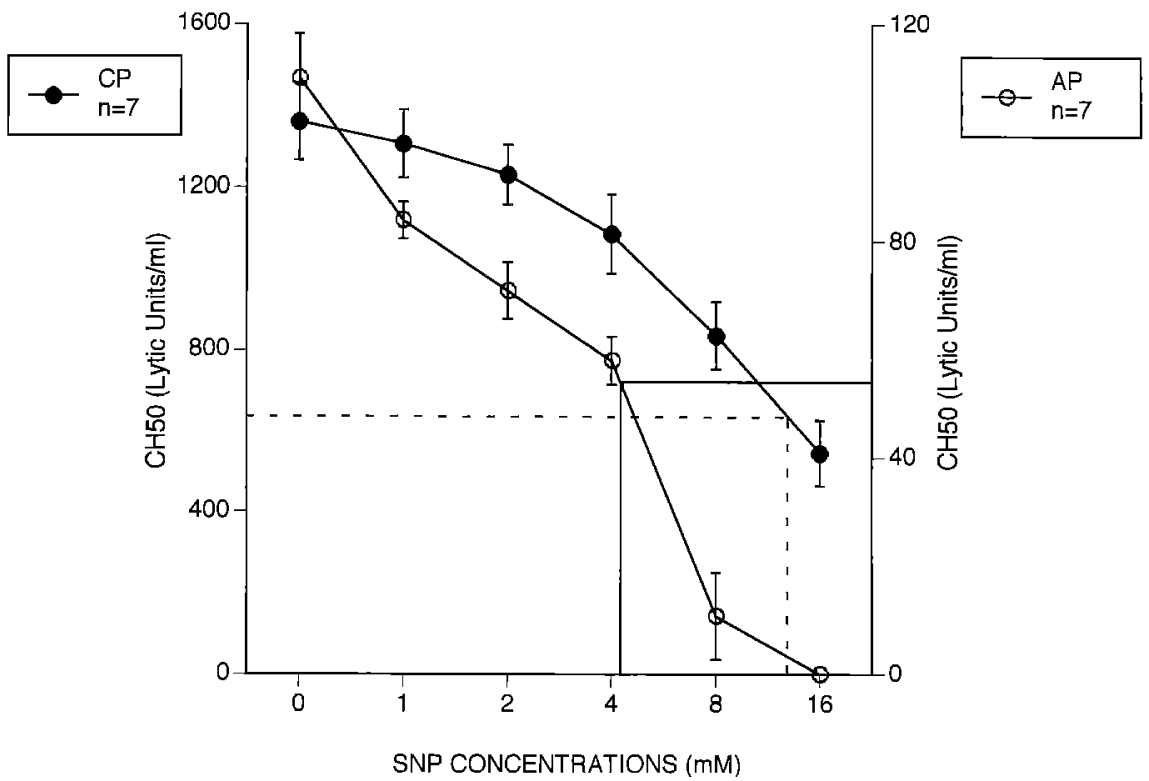

Fig. 2. Effect of increasing concentrations of SNP on $\mathrm{CH}_{50}(n=7)$. Results are expressed by the mean \pm SEM. The $50 \%$ inhibitory concentration on $\mathrm{CH}_{50}$ for the classic $(C P)$ and the alternate $(A P)$ pathways are indicated by the projected lines.

Table IV. Effect of light-degradation on the $50 \%$ inhibitory concentration of SNP on the available $\mathrm{CH}_{50}$, by the classic and the alternate pathways

\begin{tabular}{lccc}
\hline & \multicolumn{5}{c}{$50 \%$ Inhibitory concentration } & \\
& on $\mathrm{CH}_{50}($ mmol/L) & \\
\cline { 2 - 3 } & $\begin{array}{c}\text { Nonphotodegraded Photodegraded } \\
\text { SNP }\end{array}$ & $\begin{array}{c}p \\
\text { SNP }\end{array}$ & Value \\
\hline Classic pathway & $14.0 \pm 2.88$ & $2.7 \pm 0.3$ & $<0.001^{*}$ \\
Alternate pathway & $4.2 \pm 0.8$ & $0.2 \pm 0.02$ & $<0.001^{*}$
\end{tabular}

*Mann-Whitney U test.

in previous works, ${ }^{8,11,13} \mathrm{C} 4$ levels were not significantly modified during CPB. The influence of SNP on the classic pathway of the complement cascade can therefore not be fully evaluated here. The leukocyte traffic during the rewarming period, but not after protamine administration, was affected by the treatment with SNP, inasmuch as the leukocyte count was significantly lower in the current patient group than in our reference group. Because leukocyte count during the rewarming period of CPB depends on the number of cells trapped in the lungs and also on the number of cells being demarginated at the same time owing to restoration of pulmonary flow, ${ }^{6,28}$ the lower leukocyte count we measured in our patients treated with SNP could theoretically be explained in two opposite directions, namely higher intrapulmonary leukocyte trapping or lesser leukocyte mobilization. The net increase of leukocyte mobilization after protamine administration leading to similar counts of circulating leukocytes and leukocyte elastase release in our patients treated with SNP and in those not treated with SNP suggests the participation of complement-independent factors of leukocyte stimulation, such as rewarming of the patient ${ }^{28}$ and other chemotactic mediators liberated in response to $\mathrm{CPB}^{29}$

To verify the hypothesis of the complementinhibiting effect of SNP and to investigate its mechanism of action, we conducted a series of in vitro experiments in our laboratory. These showed that SNP inhibits complement activation by both the classic and the alternate pathways, and that this inhibition is dose-dependent. Our experiments clearly show an inhibitory effect on the $\mathrm{C} 3$ to $\mathrm{C} 9$ steps of the complement cascade activated by the $\mathrm{C} 3$ convertase, independent of the path of initiation (classic or alternate), the effect of SNP on the alternate pathway occurring at a concentration that was three times less than the inhibitory concentration on the classic pathway. However, this difference must be interpreted with caution because it could be related to our experimental methods: activation of the alternate pathway measured with rabbit red cell hemolysis occurs with about ten times less efficiency than the classic pathway-induced hemolysis of sensitized sheep red cells, thus involving much less generation of $\mathrm{C} 3$ convertase. With similar sensitivity to inhibitory conditions, C3 convertase generation 


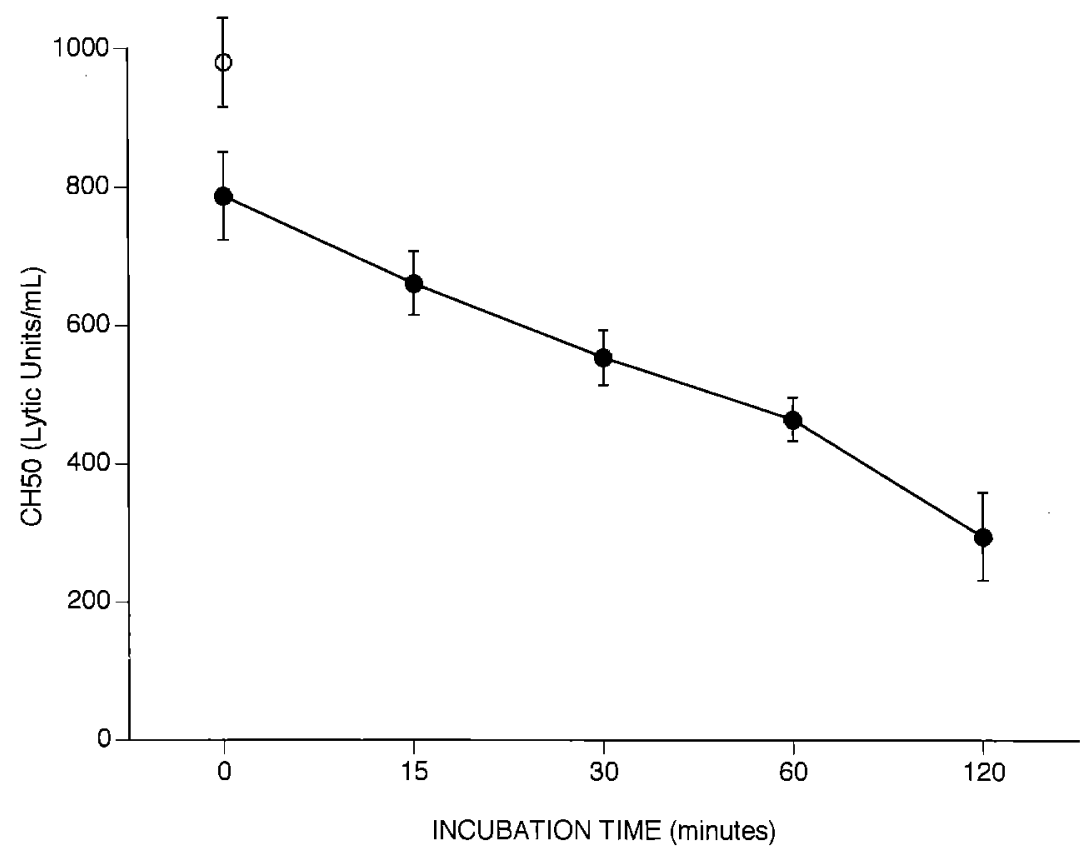

Fig. 3. Effect of preincubation with photodegraded SNP $(0.6 \mathrm{mmol} / \mathrm{L})$ on $\mathrm{CH}_{50}$ by activation of the classic pathway (black circles). Results are expressed by the mean \pm SEM. The open circle represents the control sera $(n=6)$.

or activity induced by the alternate pathway would be more easily inhibited than $\mathrm{C} 3$ convertase induced by the classic pathway. Because the zymosan-induced C3d generation is inhibited by SNP in buffer conditions allowing the alternate pathway to be activated exclusively, the $\mathrm{C} 3$ convertase of the alternate pathway must be one of the targets for this inhibitory effect. Specific site(s) of action of SNP on the complement cascade remain(s) to be elucidated in further studies.

Photodegradation of SNP and preincubation of the sera tested with SNP increased the inhibitory effect on the complement lytic activity in vitro, suggesting the role of a metabolite of SNP responsible for this effect. We excluded the SNP metabolites ferrocyanide and cyanide for this role. SNP containing a nitrogen in a low oxidative state releases nitric oxide by a nonenzymatic mechanism involving a simple one-electron reduction. ${ }^{30}$ Light exposure of SNP, as well as a variety of reducing agents, induces nitric oxide release from SNP in this way. ${ }^{31}$ We suggest that the inhibitory effect of SNP on the complement lytic activity measured in vitro and on the C3 conversion and CSa liberation measured in vivo is mediated by nitric oxide. This contention is supported by the similar inhibitory effect on the complement hemolytic activity that we observed in vitro with nitroglycerin and isosorbide dinitrate, which are other vasodilators releasing nitric oxide by mechanisms involving an enzymatic reaction. ${ }^{25}$ To the best of our knowledge, this is the first report on the anticomplementary properties of nitric oxide demonstrated in vitro and in vivo, increasing the number of its previously described properties. $^{32-34}$

In our clinical observations, complement activation during $\mathrm{CPB}$ and after protamine administration was reduced in patients treated with SNP but not totally abolished. It must be noted that the initial purpose of this clinical study was not to investigate the unexpected inhibitory effect of SNP on complement activation in patients undergoing cardiac operations. SNP was administered as a vasodilator, and its nonuniform dosage was adapted to each hemodynamic situation. The dose-dependency of the anticomplementary effect of SNP demonstrated in vitro could explain the attenuation but not the total inhibition of complement activation in our patients. In our in vitro experiments using hemolytic tests $\left(\mathrm{CH}_{50}\right)$ for the study of the inhibitory effect of SNP on complement activation, relatively large doses of SNP were necessary to show a positive effect. These concentrations (ranging from 0.2 to 1 $\mathrm{mmol} / \mathrm{L}$ ) correspond to about 60 to $300 \mathrm{mg} / \mathrm{L}$, the 30- to 100-fold amount of SNP infused to a child receiving $2 \mu \mathrm{g} / \mathrm{kg}$ per minute over 1 hour. 


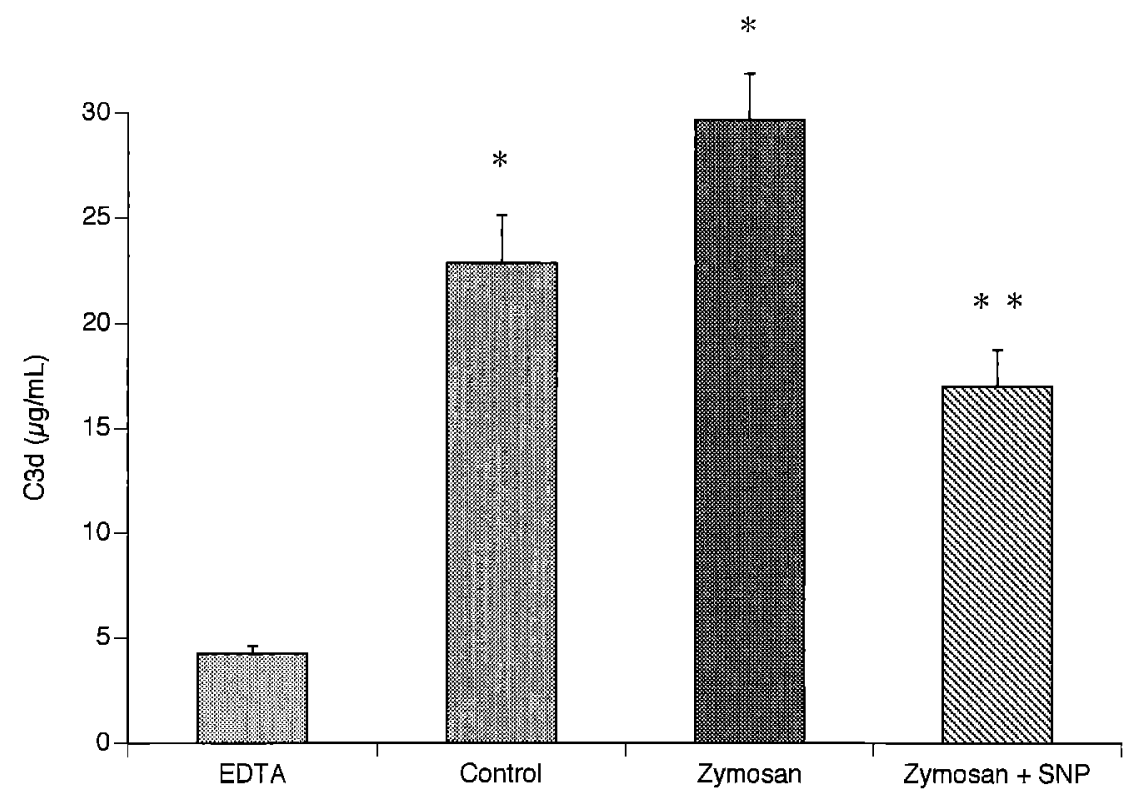

Fig. 4. C3d generation measured in plastic tubes containing ethylenediaminetetraacetic acid (EDTA) is significantly inhibited compared with $\mathrm{C} 3 \mathrm{~d}$ generation in plastic tubes where the alternate pathway is activated (asterisk) $(p<0.001)$. Zymosan-induced C3d conversion is significant compared with the control serum (asterisk) ( $p<0.001$ ). SNP significantly limits C3d generation caused by zymosan addition (double asterisks) $(p<0.0001)$, reducing C3d levels below the value measured in the control serum $(p<0.001)$ (paired $t$ test). Results are expressed as mean $\pm \operatorname{SEM}(n=5)$.

Hemolytic tests leading necessarily to the presence of free hemoglobin inactivating nitric oxide ${ }^{31}$ introduce a negative bias in the study of the doseresponse relationship of SNP as an anticomplementary substance. Efficient in vivo concentrations of SNP are probably far lower than those necessary to produce an equivalent effect in vitro, but at present the dose-response relationship of the anticomplementary effect of SNP would be difficult to establish. Indeed, liberation of nitric oxide from SNP in vivo is a dynamic and nonlinear process depending on the ubiquitous presence of several reducing (activating nitric oxide release) or oxidizing (inhibiting nitric oxide release) agents. ${ }^{31}$ Their concentrations vary from tissue to tissue and are necessarily different in the healthy subject and in the patient undergoing $\mathrm{CPB}$; the latter is subjected to an inflammatory process associated with the extracellular liberation of substances able to locally inhibit or enhance the generation or the action of nitric oxide, as do, among others, free hemoglobin and the superoxide anion. ${ }^{31,35}$ Furthermore, in our clinical model involving profound hypothermia, the temperature dependence of SNP reduction, which was clearly demonstrated in vitro in a range of temperatures between $15^{\circ}$ and $30^{\circ} \mathrm{C},{ }^{31}$ could certainly negatively influence nitric oxide release.

It was recently suggested in an animal model that SNP-by nitric oxide release-attenuates revascularization lung injury by inhibition of pulmonary neutrophil influx..$^{36}$ It is possible that attenuated C3 conversion and especially $\mathrm{C} 5 \mathrm{a}$ liberation has been responsible for some of the SNP effects reported in that study. Moreover, endogenous nitric oxide has been demonstrated to inhibit leukocyte adhesion by a mechanism involving the regulation of the leukocyte adhesion molecules. ${ }^{37}$ More recently, similar effects were shown with a novel nitric oxide donor. ${ }^{38}$ Thus both exogenous and endogenous nitric oxide inhibit leukocyte adherence to the endothelium, and this effect is protective in experimental models involving ischemia and reperfusion and thus could be beneficial in the treatment of patients undergoing cardiac operations. Whether SNP had influenced perioperative leukocyte adhesion in our patients cannot be definitively assessed here, as discussed earlier.

The clinical relevance of attenuated complement activation by SNP could not be clearly demonstrated in the clinical part of our study because, although multiple system organ failure became less prevalent 


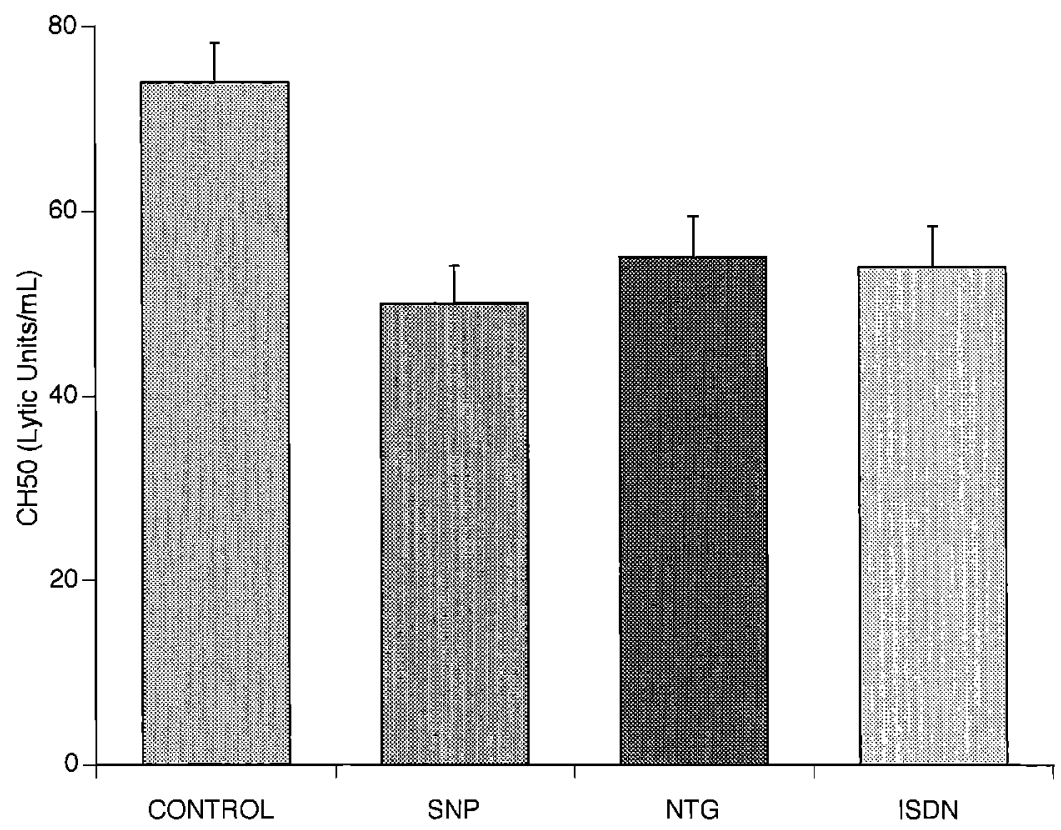

Fig. 5. Comparative effect of nonphotodegraded SNP $(1 \mathrm{mmol} / \mathrm{L})$, nitroglycerin $(N T G)(1 \mathrm{mmol} / \mathrm{L})$, and isosorbide dinitrate $(I S D N)(1 \mathrm{mmol} / \mathrm{L})$ on $\mathrm{CH}_{50}$ by the alternate pathway. Similar significant reduction of $\mathrm{CH}_{50}$ is seen in all cases of sera treated with nitrovasodilators compared with the control sera $(p<0.05$, Wilcoxon test) $(n=6)$. Results are expressed as mean $\pm \operatorname{SEM}(n=6)$.

in patients who received SNP than in the untreated patient group, the difference was not statistically significant. The indubitable demonstration of the clinical benefit of administering SNP during CPB needs a prospective randomized study on a much larger series, which we will not be able to conduct for ethical reasons. In our overall experience, multiple organ system failure became significantly less prevalent after SNP was introduced in our CPB protocol. ${ }^{39}$ Thus we believe we cannot randomize to a non-SNP group. At present, SNP has numerous advantages over other intravenous nitric oxide donors available for clinical use. ${ }^{25}$ Its pharmacologic and long known hemodynamic properties induce systemic and also pulmonary vasodilation. ${ }^{40} \mathrm{SNP}$ also was recently demonstrated to induce left ventricular relaxation and to improve left ventricular diastolic function in adults. ${ }^{41}$ Furthermore, in children undergoing cardiac operations it improved the postoperative cardiac index and did not cause related thiocyanate toxicity. ${ }^{42,43}$ Last, SNP displays a low cost efficiency ratio.

In conclusion, we showed in vitro that SNP inhibits, most probably by nitric oxide release, complement system activation initiated through either the alternate or the classic pathway. In our clinical study, CPB-induced C3 conversion and C5a libera- tion were less in patients receiving SNP for perioperative vasodilation than in patients who were not treated with SNP. The anticomplementary properties of SNP, combined with its hemodynamic effects, suggests that SNP is the vasodilator of choice for patients undergoing cardiac operations.

We thank K. Buro for advice in statistical analysis and I. Sprangers, H. Collet, and H. Schreyen for technical assistance.

\section{REFERENCES}

1. Butler $\mathbf{J}$, Rocker GM, Westaby S. Inflammatory response to cardiopulmonary bypass. Ann Thorac Surg 1993;55:552-9.

2. Donnelly SC, Haslett C, Dransfield I, et al. Role of selectins in development of adult respiratory distress syndrome. Lancet 1994;344:215-9.

3. Law SKA, Reid KBM. Activation and control of the complement system. In: Male D, Rickwood D, eds. Complement. Oxford: IRL Press, 1988:9-27.

4. Moat NE, Shore DF, Evans TW. Organ dysfunction and cardiopulmonary bypass: the role of complement and complement regulatory proteins. Eur J Cardiothorac Surg 1993; 7:563-73.

5. Kirklin JK, Westaby S, Blackstone EH, et al. Complement and the damaging effects of cardiopulmonary bypass. $J$ Thorac Cardiovasc Surg 1983;86:845-57.

6. Chenoweth DE, Cooper SW, Hugli TE, et al. Complement activation during cardiopulmonary bypass: evidence for gen- 
eration of C3a and C5a anaphylatoxins. N Engl J Med 1981;304:497-503.

7. Hammerschmidt DE, Stroncek DF, Bowers TK, et al. Complement activation and neutropenia occurring during cardiopulmonary bypass. J Thorac CARdiovasc Surg 1981;81: 370-7.

8. Steinberg JB, Kapelanski DP, Olson JD, et al. Cytokine and complement levels in patients undergoing cardiopulmonary bypass. J Thorac Cardiovasc Surg 1993;106:1008-16.

9. Haeffner-Cavaillon N, Rousselier N, Ponzio O, et al. Induction of interleukin-1 production in patients undergoing cardiopulmonary bypass. J THORAC CARDIOVASC SURG 1989;98: $1100-6$.

10. Butler J, Pillai R, Rocker GM, et al. Effect of cardiopulmonary bypass on systemic release of neutrophil elastase and tumor necrosis factor. J THORAC CARDIOVASC SURG 1993; 105:25-30.

11. Cavarocchi NC, England MD, Schaff HV, et al. Oxygen free radical generation during cardiopulmonary bypass: correlation with complement activation. Circulation 1986;74: (Suppl):III130-3.

12. Scholz W, McClurg ML, Cardenas GJ, et al. C5a-mediated release of interleukin 6 by human monocytes. Clin lmmunol lmmunopathol 1990;57:297-307.

13. Seghaye MC, Duchateau J, Grabitz RG, et al. Complement activation during cardiopulmonary bypass in infants and children: relation to postoperative multiple system organ failure. J THOrac Cardiovasc Surg 1993;106:978-87.

14. Smith WB, Gamble JR, Clark-Lewis I, et al. Interleukin-8 induces neutrophil transendothelial migration. Immunology 1991;72:65-72.

15. Tennenberg SD, Bailey WW, Cotta LA, et al. The effects of methylprednisolone on complement-mediated neutrophil activation during cardiopulmonary bypass. Surgery 1986;100: $134-42$.

16. Andersen LW, Baek L, Thomsen BS, et al. Effect of methylprednisolone on endotoxaemia and complement activation during cardiac surgery. J Cardiothorac Anesth 1989;3:544-9.

17. Jansen NJG, van Oeveren $W$, van Vliet $M$, et al. The role of different types of corticosteroids on the inflammatory mediators in cardiopulmonary bypass. Eur J Cardiothorac Surg 1991;5:211-7.

18. Van Oeveren W, Jansen NJG, Bidstrup BP, et al. Effects of aprotinin on hemostatic mechanisms during cardiopulmonary bypass. Anп Thorac Surg 1987; 44:640-5.

19. Blauhut B, Gross C, Nececk S, et al. Effects of high dose aprotinin on blood loss, platelet function, fibrinolysis, complement, and renal function after cardiopulmonary bypass. J Thorac Cardiovasc Surg 1991;101:958-67.

20. Wachtfogel YT, Kucich U, Hack CE, et al. Aprotinin inhibits the contact, neutrophil, and platelet activation systems during simulated extracorporeal perfusion. J THORAC CARDIOVASC SuRG 1993;106:1-10.

21. Welsch CH, Lien D, Worthen GS, et al. Pentoxifylline decreases endotoxin-induced pulmonary neutrophil sequestration in the dog. Am Rev Respir Dis 1988;138:1106-14.

22. Mandell G, Novick W, eds. Proceedings of a symposium: pentoxifylline and leukocyte function. Somerville, New Jersey: Hoechst-Roussel Pharm Inc, 1988:199-210.

23. Moat NE, MacNaughton PD, Pallares LCM, et al. Complement inhibition may attenuate acute lung injury after cardio- pulmonary bypass in pigs [Abstract]. Am Rev Respir Dis 1992;145:A845.

24. Palmer R, Lasseter KC. Sodium nitroprusside. N Engl J Med 1975;292:294-7.

25. Harrisson DG, Bates JN. The nitrovasodilators: new ideas about old drugs. Circulation 1993;87:1461-7.

26. Price CP, Spencer K, Whicker J. Light-scattering immunoassay of specific proteins: a review. Ann Clin Biochem 1983;20: $1-14$.

27. Servais G, Walmagh J, Duchateau J. Simple quantitative haemolytic microassay for determination of complement alternative pathway activation. J Immunol Methods 1991;140:93-100.

28. Quiroga MM, Miyagishima R, Haendschen LC, et al. The effect of body temperature on leukocyte kinetics during cardiopulmonary bypass. J Thorac Cardiovasc Surg 1985;90:91-6.

29. Kalfin RE, Engelman RM, Rousou JA, et al. Induction of interleukin-8 expression during cardiopulmonary bypass. Circulation 1993;88:401-6.

30. Arnold WP, Longnecker DE, Epstein RM. Photodegradation of sodium nitroprusside: biologic activity and cyanide release. Anesthesiology 1984;61:254-60.

31. Bates JN, Baker MT, Guerra R Jr, et al. Nitric oxide generation from nitroprusside by vascular tissue: evidence that reduction of the nitroprusside anion and cyanide loss are required. Biochem Pharmacol 1991;42(Suppl):157-65.

32. Moncada S, Palmer RMJ, Higgs A. Nitric oxide: physiology, pathophysiology, and pharmacology. Pharmacol Rev 1991; 43:109-42.

33. Moncada S, Higgs A. The L-arginine-nitric oxide pathway. $N$ Engl J Med 1993;329:2002-12.

34. Änggard E. Nitric oxide: mediator, murderer and medicine. Lancet 1994;343:1199-206.

35. Oury T, Ho Y-S, Piantadosi CA, et al. Extracellular superoxide dismutase, nitric oxide, and central nervous system $\mathrm{O}_{2}$ toxicity. Proc Natl Acad Sci U S A 1992;89:9715-9.

36. Abdih H, Kelly CJ, Bouchier-Hayes D, et al. Nitric oxide (endothelium-derived relaxing factor) attenuates revascularization-induced lung injury. J Surg Res 1994;57:39-43.

37. Kubes P, Suzuki M, Granger DN. Nitric oxide: an endogenous modulator of leukocyte adhesion. Physiol Pharmacol 1991;88:4651-5.

38. Lefer DJ, Nakanishi K, Johnston WE, et al. Antineutrophil and myocardial protecting actions of a novel nitric oxide donor after acute myocardial ischemia and reperfusion in dogs. Circulation 1993;88:2337-50.

39. Seghaye MC, Duchateau J, Grabitz RG, et al. Perioperative Anwendung von Natriumnitroprussid zur Reduktion von Herz-Lungen-Maschinen-induzierten Komplikationen beim Kind [Abstract]. Z Kardiol 1992;81:58.

40. Bixler TJ, Gott VL, Gardner TJ. Reversal of experimental pulmonary hypertension with sodium nitroprusside. J THORAC CARDIOVASC SURG 1981;81:537-45.

41. Paulus WJ, Vantripont PJ, Shah A. Acute effects of nitric oxide on left ventricular relaxation and diastolic distensibility in humans: assessment by bicoronary sodium nitroprusside infusion. Circulation 1994:89:2070-8.

42. Benzig G III, Helmsworth JA, Schreiber T, et al. Nitroprusside and epinephrine for treatment of low output in children after open-heart surgery. Ann Thorac Surg 1979;27:523-8.

43. Kunathai S, Sholler GF, Celermajer JM, et al. Nitroprusside in children after cardiopulmonary bypass: a study of thiocyanate toxicity. Pediatr Cardiol 1989;10:121-4. 